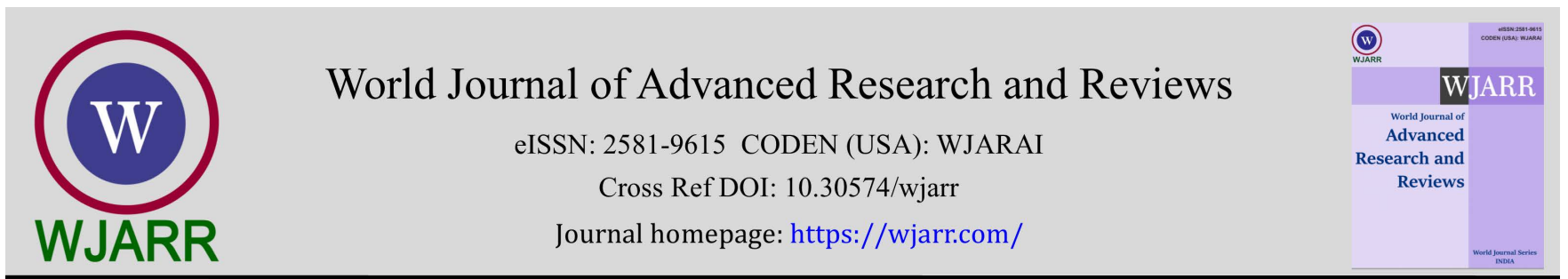

(RESEARCH ARTICLE)

Check for updates

\title{
Control of the use of Sogobalo in the production of growth feeds for broiler chickens in Cote D'ivoire
}

\author{
Bouatene Djakalia ${ }^{1,}{ }^{*}$, Koffi Kouassi Marcel ${ }^{1}$, N'goran Evelyne Patricia Abo ${ }^{2}$ and Bohoua Louis Guichard 1 \\ ${ }^{1}$ Department of Food Science and Technology, University Nangui Abrogoua, 02 BP 801 Abidjan 02, Côte d'Ivoire. \\ ${ }^{2}$ National Center for Agronomic Research, 08 BP 881 Abidjan 08, Ivory Coast.
}

World Journal of Advanced Research and Reviews, 2021, 10(03), 302-311

Publication history: Received on 13 May 2021; revised on 16 June 2021; accepted on 18 June 2021

Article DOI: https://doi.org/10.30574/wjarr.2021.10.3.0232

\begin{abstract}
In poultry farming, the management of feed inputs is decisive in production. This study is to optimize the feed use of sogobalo in breeding broilers to improve growth performance. To do this, five feeds different by their proportion of sogobalo were formulated and used to feed five batches of broilers in the growth phase. Each of the five batches received a specific feed. The five feeds under study consist of a growth staple supplemented respectively with $0 \% ; 2.5 \% ; 5 \%$; $7.5 \%$ and $10 \%$ of sogobalo. In order to assess the effect of the supplementation rate of sogobalo, body weight, feed intake, weight gain, and consumption index and mortality rate were determined. The results showed that the animals which received the incorporation of sogobalo at $10 \%$ were the heaviest $(3282 \mathrm{~g} \pm 17.00)$. The consumption index was lower in the batch of chicken whose sogobalo supplementation was 10\% (3.17 \pm 1.00$)$ compared to the other batches $(3.36 \pm 1.00 ; 3.54 \pm 1,00 ; 3.76 \pm 1.00$ and $3.95 \pm 1.00$ respectively for animals of the batches of $7.5 \% ; 5 \% ; 2.5 \%$ and $0 \%)$. The weight gain was significantly $(\mathrm{P}<0.05)$ higher for the $10 \%$ supplemented group $(529 \mathrm{~g} \pm 10.00)$. No mortality was observed in the supplemented batch. On the other hand, in the control batch, a higher mortality rate (4\%) was recorded. The supplementation with $10 \%$ of sogobalo optimizes the growth performance and the health of broilers.
\end{abstract}

Keywords: Broiler; Mortality; Growth performance; Sogobalo

\section{Introduction}

Population growth in Côte d'Ivoire, especially in the Abidjan (economic capital), has increased the needs of its population. Among the primary needs that this growing population must meet is access to food, hence the need to increase the availability of good quality animal proteins at a lower cost on the market. The predominant share of feed in the cost price of poultry is estimated at 70\% [1,2] and the perpetual search for the best economic results is pushing scientists and industrialists in the poultry sector towards search for a nutritional optimum [3]. The search for the nutritional optimum involves complex concepts both in terms of feed and animals. These include, among others, the environment of feed formulation, the mechanisms determining the ingestion and digestion and then the use of nutrients. A complete feed for poultry must be balanced in energy, protein, mineral salts and vitamins (knowledge of raw materials and improvement of manufacturing processes).

The scarcity and high cost of feed inputs for poultry are also a concern for Ivorian producers. The immediate consequences of this situation are the increased cost of feed and chicken. To these many difficulties for poultry farmers, add, the massive imports of poultry carcasses deemed harmful to the economy and health [4].

In view of these different concerns, there is a need to search for inexpensive feed sources that are perfectly suited to the needs of poultry. There are many conventional feed sources used for poultry. These are peanuts, soybeans, palm kernel

\footnotetext{
${ }^{*}$ Corresponding author: Bouatene Djakalia

Department of Food Science and Technology, University Nangui Abrogoua, 02 BP 801 Abidjan 02, Côte d'Ivoire.
}

Copyright $(2021$ Author(s) retain the copyright of this article. This article is published under the terms of the Creative Commons Attribution Liscense 4.0. 
meal, corn, fish etc. however, their production is often low and the demand for these materials is very high at the national and regional level. Also their high cost does not guarantee the stability of poultry farming.

To overcome this situation, the use of sogobalo is being considered. Sogobalo is a derivative of wheat. It is used as a supplement in sheep feed. Sogobalo is rich in nutrients [5]. In addition to its high nutritional value, sogobalo has a lower cost. Its social price on the market strongly attracts breeders. Its use in livestock feed is generally based on the needs of the animals and the biochemical composition of the feed [6]. Its use in sheep feed provides a balanced ration and a reduction in the quantity of different raw materials used in the formulation of maintenance and production [7]. Various scientific studies have noted the importance of the use of sogobalo in animal feed. But in these studies, it is not mentioned the optimal level of use. According to the study of Bouatene et al. [8], sogobalo is thought to promote growth of chickens in the start-up phase. However, in this work it is not mentioned at what rate of incorporation the efficiency of sogobalo is maximized. As for the work of Alla [9] on antenaises, sogobalo was used at 3.33\%. The latter concluded that this amount had been determined on the basis of the needs of the animals and the biochemical composition of the feed. Its use in the ration of antenaises generated performances (ADG, weight growth) superior to those of antenaises, fed only with Panicum maximum. In this study it is unfortunately not mentioned the effect of the change in sogobalo rates.

The objective of this study is to optimize the feed use of sogobalo in the breeding of broilers. This specifically involves determining the effect of the variation in the rate of incorporation of sogobalo in the feed on the weight mass, the weight gain, the consumption index and the mortality rate of broilers in phase of growth.

\section{Material and methods}

The study took place in the district of Abidjan precisely in the locality of Bingerville (Côte d'Ivoire). This locality is characterized by a humid tropical climate which has a very high temperature and humidity respectively $33{ }^{\circ} \mathrm{C}$ and $68 \%$.

\subsection{Housing}

The animals were kept inside a modern livestock building which is built in the open air and oriented on an axis perpendicular to the winds. The building is characterized by a length of $20 \mathrm{~m}$, a width of $7 \mathrm{~m}$ and a height of $3.5 \mathrm{~m}$. At the entrance of the building is installed a footbath which served as disinfectant.

\subsection{Animals}

Animals used for the study are flesh chicks Cobb 500 strain which come from a hatchery situated in the district of Abobo (Abidjan). Initially 1000 chicks' one day old and average weight of $53 \mathrm{~g} \pm 1.52$ were reared up to 4 weeks. For the realization of the experiment, on day 29,500 unsexed chickens were selected with an average weight of $1208 \mathrm{~g} \pm 11.02$. These Five hundred chickens aged 29 days and unsexed were divided into five lots of 100 chickens.

\subsection{Feeds}

Five feeds different in their proportion of sogobalo were formulated and used to feed the five batches of broilers for three weeks. The feed is presented in the form of flour. The five feeds under study consist of a staple feed supplemented with $0 \%$ respectively; $2.5 \% ; 5 \% ; 7.5 \%$ and $10 \%$ sogobalo. The staple feed is a standard growth feed manufactured by the company Labograin-Afrique.

\subsection{Weighing scale}

The weighing of the feed, the refusals and the quantities of feed distributed, as well as the animals, required the use of two scales (a scale of $5 \mathrm{~kg}$ capacity and another of $20 \mathrm{~kg}$ ). A weighing scale with a capacity of $20 \mathrm{~kg}$ was used to weigh the feed (distributed feed and feed refusals). Another $5 \mathrm{~kg}$ scale made it possible to weigh the chickens weekly.

\subsection{Technical monitoring}

Initially, the chicks numbered 1000. They were fed starter feed for the first 4 weeks. Then for the study, 500 unsexed chickens aged 29 days were chosen and divided into five batches. Each batch contained 100 chickens. The distribution of animals per batch was made at random. For lighting, four neon bulbs of 75 watts were suspended above the different batches to allow subjects to eat and drink. Regarding hygiene, the litter is changed every five days and the drinkers are washed every two days to prevent bacterial diseases. To accurately monitor the temperature during the test, a temperature sheet has been drawn up. From the 30th to the $49^{\text {th }}$ day, the temperature varied between $26^{\circ} \mathrm{C}$ and $28{ }^{\circ} \mathrm{C}$. The experiment was repeated three times. 


\subsection{Feeding and weighing chickens}

During three weeks of experience, each batch of chickens received a specific feed. Each feed is distributed two times per day. The first ration is distributed in the morning at 7:30 a.m. and the second ration is served in the afternoon at 4 p.m. The feed is distributed at will. Every morning at 7:30 am, the feed refusals are removed from the feeders and weighed to determine the growth parameters (average weight, weight gain and consumption index). The drinking water is distributed at will. This water comes from the national water distribution network. The weights of the chickens at different ages were determined weekly. The weighings were carried out before the distribution of the feed.

\subsection{Sanitary and prophylactic management}

The adopted sanitary prophylaxis program is that of Cobb [10]. The breeding equipment was soaked in water containing $0.25 \%$ of potassium sulphate and persulphate (VIRUNETND) to be disinfected, then washed thoroughly with drinking water. Table 1 shows the prophylaxis program used.

Table 1 Prophylaxis used during the trial

\begin{tabular}{|c|l|l|}
\hline Age (days) & \multicolumn{1}{|c|}{ Products used } & \multicolumn{1}{|c|}{ Actions } \\
\hline 1 & Sugar water & Anti-stress \\
\hline $2-3-4$ & Tylodox & Antibacterial \\
\hline $5-6$ & Amin total & Stress prevention \\
\hline 7 & HB1 + H120 (drinking water) & $\begin{array}{l}\text { Vaccination against New castel disease and } \\
\text { Infectious Bronchitis }\end{array}$ \\
\hline $8-11$ & Amin total & Stress prevention \\
\hline 12 & 1 st Recall IBL Gumboro (drinking water) & Vaccination against Gumboro \\
\hline $13-15$ & Amin total & Stress prevention \\
\hline 16 & 2 nd IBL Gumboro recall (drinking water) & Vaccination against Gumboro \\
\hline $17-19$ & Vetacox & Anticoccidial \\
\hline 20 & Amin total & Stress prevention \\
\hline 21 & H120 / Sota (drinking water) & Vaccination against plague \\
\hline $22-26$ & Amin total & Stress prevention \\
\hline $27-29$ & Vetacox recall & Antibacterial \\
\hline $30-35$ & Amin total & Stress prevention \\
\hline $36-49$ & Simple water & Watering \\
\hline
\end{tabular}

\section{Determination of growth performance parameters}

\subsection{Average weight}

The average weights of the chickens were determined according to the formula of Bouatene et al [11].

$$
\mathrm{AW}(\mathrm{g})=\frac{\mathrm{TWS}}{\mathrm{NS}}
$$

AW: Average weight of chickens (g);

TWS: Total Weight of the Subjects of a given batch;

NS: Number of subjects of this batch. 


\subsection{Weight gain}

The calculated of average weights were used to determine the average weight gains of the chickens per week. The calculation was made according to the formula of Bouatene et al [11].

$$
A W G=A W 2-A W 1
$$

AWG: Average weight gains (g);

$\mathrm{AW}_{1}$ : Average weight of the previous week (g);

$\mathrm{AW}_{2}$ : Poids Moyen de la semaine suivante (g).

\subsection{Consumption index (CI)}

It represents the relationship between the amount of feed eaten and weight gain. It was evaluated from the formula of Mingoas et al [12].

$$
C L=\frac{\text { Amount of feed consumed during the week }(\mathrm{g})}{\text { Weight gain of the week }(\mathrm{g})}
$$

\subsection{Mortality Rate}

The mortality rate (MR) corresponds to the ratio between the total number of dead subjects and the initial number of subjects of this batch during a period considered. It was determined according to the method of Bouatene et al [11].

$$
M R=\frac{\text { Total number of dead subjects }}{\text { Total number of dead subjects }} \times 100
$$

\section{Determination of physico-chemical composition of feeds}

Feeds and supplements were analyzed for energy values, protein, crude fiber, fat, ash and minerals. The chemical analyzes were carried out at the Central Analysis Laboratory (LCA) of the University Nangui Abrogoua (UNA).

The value of the metabolizable energy (ME) is obtained by calculation from the fat, cellulose and ash levels of the sample. This value is determined according to the method of AOAC [13].

The total nitrogen content is determined by KJEDAHL according to the method of AOAC [13]. The nitrogen content obtained affected by the conversion coefficient 6.25 made it possible to estimate the total protein content.

The dosage of the cellulose is carried out according to the method of AOAC [13].

The fat content was determined using the soxhlet apparatus according to AOAC [13].

The crude ash content is determined by subtracting from the dry matter (DM) rate, the organic matter (OM) content.

The quantification of the minerals was done by Atomic Absorption Spectroscopy (AAS) in accordance with AFNOR [14] instructions.

\section{Statistical analysis}

The data collected was entered using the Excel® 2007 computer spreadsheet, Microsoft Corporation. Statistical analysis was performed using Statistica software, StatSoft, version 7.0 (2009). The average values were subjected to an analysis of variance (ANOVA) and compared to a factor according to the multiple range test of Duncan at the $5 \%$ threshold. It was used to calculate the average and make a ranking based on performance. The mean value is accompanied by the standard error on the mean (Mean \pm SEM). 


\section{Results}

\subsection{Chemical composition of standard feed and sogobalo}

Tables 2 and 3 show the profiles of the growing feed and sogobalo, respectively. It emerges from these tables that the growth feed is energetic (3069 kcal), it is rich in protein (18\%) and in mineral elements (potassium and sodium). As for sogobalo, it is also energetic $(2100 \mathrm{kcal})$, rich in protein $(21 \%)$ and minerals such as Calcium $(14.8 \mathrm{~g} / \mathrm{kg})$ and Magnesium (3 g / kg).

Table 2 Nutritional profile of the standard feed

\begin{tabular}{|l|l|}
\hline Composition & Growth staple feed \\
\hline Metabolizable energy (kcal) & $3069 \pm 63.74$ \\
\hline Crude protein (\%) & $18 \pm 2.00$ \\
\hline Crude fiber (\%) & $3.75 \pm 0.07$ \\
\hline Fat (\%) & $4.28 \pm 0.02$ \\
\hline crude ash (\%) & $5.5 \pm 0.63$ \\
\hline $\mathrm{K}(\mathrm{g} / \mathrm{kg})$ & $17.65 \pm 0.75$ \\
\hline $\mathrm{Mg}(\mathrm{g} / \mathrm{kg})$ & $2.27 \pm 3.79$ \\
\hline $\mathrm{Fe}(\mathrm{g} / \mathrm{kg})$ & $0,41 \pm 14,63$ \\
\hline $\mathrm{Na}(\mathrm{g} / \mathrm{kg})$ & $9,23 \pm 0,67$ \\
\hline $\mathrm{Ca}(\mathrm{g} / \mathrm{kg})$ & $3.57 \pm 1.38$ \\
\hline $\mathrm{P}(\mathrm{g} / \mathrm{kg})$ & $2,11 \pm 3,21$ \\
\hline
\end{tabular}

Table 3 Nutritional profile of sogobalo

\begin{tabular}{|l|c|}
\hline Composition & Sogobalo \\
\hline Metabolizable energy (kcal) & $2100 \pm 2.43$ \\
\hline Crude protein (\%) & $21 \pm 0.31$ \\
\hline Crude fiber (\%) & $7.5 \pm 0.01$ \\
\hline Fat (\%) & $3 \pm 0.01$ \\
\hline Mineral matter (\%) & $9 \pm 0.34$ \\
\hline Ash (\%) & $7.5 \pm 0.03$ \\
\hline Phosphorus (g/kg) & $7.5 \pm 0.03$ \\
\hline Calcium (g/kg) & $14.8 \pm 0.17$ \\
\hline Magnesium (g/kg) & $3 \pm 0.02$ \\
\hline Iron (mg) & $35 \pm 0.04$ \\
\hline Copper (mg) & $25 \pm 0.11$ \\
\hline Zinc (mg) & $160 \pm 0.37$ \\
\hline Manganese (mg) & $21 \pm 0.02$ \\
\hline Iodine (mg) & $0.7 \pm 0.00$ \\
\hline Cobalt (mg) & $1.05 \pm 0.00$ \\
\hline Selenium (mg) & $0.2 \pm 0.00$ \\
\hline
\end{tabular}




\subsection{Average weight}

Table 4 shows the change in average weight per week. It emerges from this analysis that the average weights are different according to the rate of incorporation. The feed supplemented with $10 \%$ of sogobalo obtained the highest average weights $(3282 \mathrm{~g} \pm 17.00)$ from the start to the end of the experiment. Furthermore, the control ( $0 \%$ sogobalo) recorded the low average weight. The different average weights show significant differences $(\mathrm{P}<0.05)$. At the end of the study, the average weights obtained are in decreasing order, $3282 \mathrm{~g} \pm 17.00 ; 3103 \mathrm{~g} \pm 18.00 ; 2990 \mathrm{~g} \pm 10.02 ; 2788 \mathrm{~g} \pm$ 15.00 and $2607 \mathrm{~g} \pm 16.01$ respectively for the supplements of $10 \%, 7.5 \%, 5 \%, 2.5 \%$ and $0 \%$.

Table 4 Evaluation of average weights according to the rate of sogobalo

\begin{tabular}{|c|c|c|c|c|c|}
\hline \multirow{2}{*}{ Weeks } & \multicolumn{5}{|c|}{ Incorporation rate of sogobalo } \\
\cline { 2 - 6 } & $\mathbf{0} \%$ & $\mathbf{2 . 5} \%$ & $\mathbf{5 \%}$ & $\mathbf{7 . 5} \%$ & $\mathbf{1 0} \%$ \\
\hline 0 & $1208^{\mathrm{a}} \pm 11.02$ & $1208^{\mathrm{a}} \pm 11.02$ & $1208^{\mathrm{a}} \pm 11.02$ & $1208^{\mathrm{a}} \pm 11.02$ & $1208^{\mathrm{a}} \pm 11.01$ \\
\hline 1 & $1786^{\mathrm{e}} \pm 15.00$ & $1873^{\mathrm{d}} \pm 14.01$ & $1920^{\mathrm{c}} \pm 15.00$ & $1995^{\mathrm{b}} \pm 8.03$ & $2085^{\mathrm{a}} \pm 10.01$ \\
\hline 2 & $2212^{\mathrm{e}} \pm 19.02$ & $2380^{\mathrm{d}} \pm 20.00$ & $2510^{\mathrm{c}} \pm 11.01$ & $2598^{\mathrm{b}} \pm 17.00$ & $2753^{\mathrm{a}} \pm 21.00$ \\
\hline 3 & $2607^{\mathrm{e}} \pm 16.01$ & $2788^{\mathrm{d}} \pm 15.00$ & $2990^{\mathrm{c}} \pm 10.02$ & $3103^{\mathrm{b}} \pm 18.00$ & $3282^{\mathrm{a}} \pm 17.00$ \\
\hline
\end{tabular}

The different letters a, b, c, d, e, f on the same line means that there is a significant difference at the threshold of $5 \%$ between the values.

\subsection{Weight gain}

Table 5 shows the evolution of weight gain per week. The peak of the weight gains of the different batches is obtained from the first week. Beyond the first week, the various weight gains drop until the third week. However, the batch of chickens fed with $10 \%$ sogobalo recorded gains the highest weight every week $(877 \pm 11.00 \mathrm{~g}, 668 \mathrm{~g}$ and $529 \mathrm{~g} \pm 9.02 \pm$ $10.00)$. On the other hand, the control batch ( $\% \%$ sogobalo) obtained the low weight gains ( $578 \mathrm{~g} \pm 9.04 ; 426 \mathrm{~g} \pm 7.01$ and $395 \mathrm{~g} \pm 6.00)$. The different weight gains show significant differences $(\mathrm{P}<0.05)$. The evolution of weight gains follows the order of incorporation rates in sogobalo.

Table 5 Evaluation of weight gain according to the rate of sogobalo

\begin{tabular}{|c|c|c|c|c|c|}
\hline \multirow{2}{*}{ Weeks } & \multicolumn{5}{|c|}{ Incorporation rate of sogobalo } \\
\cline { 2 - 6 } & $\mathbf{0} \%$ & $\mathbf{2 . 5} \%$ & $\mathbf{5} \%$ & $\mathbf{7 . 5} \%$ & $\mathbf{1 0} \%$ \\
\hline $\mathbf{1}$ & $578^{\mathrm{e}} \pm 9.04$ & $665^{\mathrm{d}} \pm 10.00$ & $712^{\mathrm{c}} \pm 9.00$ & $787^{\mathrm{b}} \pm 8.01$ & $877^{\mathrm{a}} \pm 11.00$ \\
\hline $\mathbf{2}$ & $426^{\mathrm{e}} \pm 7.01$ & $507^{\mathrm{d}} \pm 9.01$ & $590^{\mathrm{c}} \pm 8.00$ & $608^{\mathrm{b}} \pm 7.00$ & $668^{\mathrm{a}} \pm 9.02$ \\
\hline $\mathbf{3}$ & $395^{\mathrm{e}} \pm 6.00$ & $408^{\mathrm{d}} \pm 5.00$ & $480^{\mathrm{c}} \pm 7.02$ & $505^{\mathrm{b}} \pm 11.00$ & $529^{\mathrm{a}} \pm 10.00$ \\
\hline
\end{tabular}

The different letters a, b, c, d, e, f on the same line means that there is a significant difference at the threshold of $5 \%$ between the values.

\subsection{Consumption Index (IC)}

Table 6 shows the evolution of the consumption index per week. As we evolve over time, the different consumption indices increase. Chickens fed with low levels of sogobalo have the highest consumption indices.

Table 6 Evaluation of the consumption indices as a function of the sogobalo rate

\begin{tabular}{|c|c|c|c|c|c|}
\hline \multirow{2}{*}{ Weeks } & \multicolumn{5}{|c|}{ Incorporation rate of sogobalo } \\
\cline { 2 - 6 } & $\mathbf{0} \%$ & $\mathbf{2 . 5} \%$ & $\mathbf{5} \%$ & $\mathbf{7 . 5} \%$ & $\mathbf{1 0} \%$ \\
\hline 1 & $1.98^{\mathrm{d}} \pm 0.00$ & $1.81^{\mathrm{c}} \pm 0.00$ & $1.60^{\mathrm{b}} \pm 0.00$ & $1.58^{\mathrm{b}} \pm 0.00$ & $1.41^{\mathrm{a}} \pm 0.00$ \\
\hline 2 & $3.50^{\mathrm{d}} \pm 1.00$ & $3.31^{\mathrm{c}} \pm 1.00$ & $2.96^{\mathrm{b}} \pm 0.50$ & $2.94^{\mathrm{b}} \pm 0.00$ & $2.55^{\mathrm{a}} \pm 0.00$ \\
\hline 3 & $3.95^{\mathrm{e}} \pm 1.00$ & $3.76^{\mathrm{d}} \pm 1.00$ & $3.54^{\mathrm{c}} \pm 1.00$ & $3.36^{\mathrm{b}} \pm 1.00$ & $3.17^{\mathrm{a}} \pm 1.00$ \\
\hline Average & $3.14^{\mathrm{e}} \pm 1.00$ & $2.96^{\mathrm{d}} \pm 1,00$ & $2.7^{\mathrm{c}} \pm 1.00$ & $2.63^{\mathrm{b}} \pm 1.00$ & $2.38^{\mathrm{a}} \pm 1.38$ \\
\hline
\end{tabular}

The different letters a, b, c, d, e, f on the same line means that there is a significant difference at the threshold of $5 \%$ between the values. 
This observation is the same every week, except from the first to the second week where no significant effect is observed between the $5 \%$ sogobalo feed and the $7.5 \%$ feed. The low consumption indices were recorded with the sogobalo batch of $10 \%$ concentration $(1.41 \pm 0.00 ; 2.55 \pm 0.00$ and $3.17 \pm 1.0)$. On the other hand, the highest consumption indices were obtained by the control batch $(1.98 \pm 0.00 ; 3.50 \pm 1.00$ and $3.95 \pm 1.00)$.

\subsection{Mortality}

Table 7 shows the evolution of the mortality rate during the test. All the mortalities noted during the experiment were recorded in the control group ( 4 dead chickens). All the cases of mortality of the control group were noted by the 3rd week of the experiment. However, no mortality was recorded in the different batches supplemented with sogobalo regardless of the incorporation rate.

Table 7 Evaluation of mortality according to the rate of sogobalo

\begin{tabular}{|c|c|c|c|c|c|}
\hline \multirow{2}{*}{ weeks } & \multicolumn{5}{|c|}{ Incorporation rate of sogobalo } \\
\cline { 2 - 6 } & $\mathbf{0} \%$ & $\mathbf{2 . 5} \%$ & $\mathbf{5 \%}$ & $\mathbf{7 . 5} \%$ & $\mathbf{1 0} \%$ \\
\hline 1 & 0 & 0 & 0 & 0 & 0 \\
\hline 2 & 0 & 0 & 0 & 0 & 0 \\
\hline 3 & 4 & 0 & 0 & 0 & 0 \\
\hline Total number of deaths & 4 & 0 & 0 & 0 & 0 \\
\hline Total number of chickens & 100 & 100 & 100 & 100 & 100 \\
\hline Mortality rate (\%) & 4 & 0 & 0 & 0 & 0 \\
\hline
\end{tabular}

\section{Discussion}

Data on weight development show an increase in the growth of chickens with age. The significant difference between the different average weights is explained by the difference in the feed rations used. Indeed, a richer diet makes it possible to obtain significantly greater growth [15]. Considering the virtues of sogobalo, its use in the feed of broilers with different incorporation rates has allowed to obtain average weights and weight gains increasing according to the supplementation rate. These results reflect the effectiveness of sogobalo. Sogobalo is known for its efficacy as one of the feed supplements used in cattle and sheep feed $[5,6]$. The study of Bouatene et al [8], showed the importance of this feed supplement in improving the growth performance of broilers in the start-up phase. The results obtained during this experiment are similar to the results of Ugwu et al [16] and Kilemba et al [17] on the incorporation of palm kernel meal in the feed of broilers. These authors varied the rate of palm kernel meal from 0 to $15 \%$ and observed that the incorporation of palm kernel meal up to $15 \%$ improved zootechnical performance (individual feed consumption, average daily gain and the consumption) of broilers and economics. However, the results of the present study are in contradiction with the results of the work of Abdou [18] and André et al [19]. Abdou [18], substituted the maize with pods of Faidherbia albida with an incorporation rate that varied from $10 \%$ to $40 \%$ and he found that when the incorporation rate increases, the growth parameters are negatively affected. As for André et al [19], they supplemented with flour from a legume, Mucuna pruriens at rates of 2.5; 18.75 and 30\%. In their work, they found that when the flour content of Mucuna pruriens is high in the chicken feed, the growth parameters were more negatively affected. The downward trend of chicken growth parameters with increasing incorporation rate was also observed in the work of Mafouo et al [20], on the partial or total substitution of maize by cassava flour in the feed of broilers.

In terms of weight gains, the results show a significant difference at the $5 \%$ level. However, there was a decrease in weight gains from the first week until the end of the study. Regarding the drop of weight gains from week 1 to the end, this trend is in agreement with the results obtained by Cobb [10]. According to Cobb [10], weight gain increases with the age of the animals and then deteriorates in the sixth week (42 days of age). Indeed, the 2nd week of this experience actually corresponds to the sixth week of the chickens' life. By comparing the results of this study with the results of Cobb [10], we see that in our case, the weight gains started to drop a week before, that is to say from the 5th week of life (1st week of our experience). It could be related to the temperature difference. Indeed, during our experiment, the temperature oscillated between $26^{\circ} \mathrm{C}$ and $28^{\circ} \mathrm{C}$ while Cobb [10] obtained its results at a temperature between $20^{\circ} \mathrm{C}$ and $24^{\circ} \mathrm{C}$. According to Hornick et al [21], temperature can affect feed consumption and subsequently affect the weight gain and feed index. In fact, the rise of ambient temperature of chickens causes a decrease of consumption and its decrease causes an increase in feed consumption. According to Washburn [22] and Tossou et al [23], chronic heat stress 
may be responsible for retarded weight growth and reduced feed intake. In addition, analysis of variance revealed a significant difference between the average weight gains depending on the ration. Over the sogobalo rate is high in the diet, the greater the weight gain is high. These results are contrary to those of Tendonkeng et al [24] and Bello [25]. The latter obtained low weight gain with an increase in the rate of incorporation of Moringa oleifera in the feed of chickens.

Regarding consumption index, the results of this study are superior to those proposed by Cobb [10], the breeder of the strain. Indeed, according to Cobb [10], the benchmark consumption index in broiler breeding is 1.90 at seven weeks of life, corresponding to the third week of our experience. This means that it takes $1.90 \mathrm{~kg}$ of feed to produce $1 \mathrm{~kg}$ of weight. The consumption index is a parameter to test the effectiveness of the diet over a period [26]. Having higher consumption indices compared to standards could be linked to wasted feed and inadequate management of feeders. The consumption index is better when it is as low as possible.

In terms of mortality, chickens fed with sogobalo recorded no mortality. Only chickens whose ration did not include sogobalo recorded mortalities. This fact reflects the effectiveness of sogobalo. Sogobalo is a quality supplement. A substantial and high-quality diet is crucial for the organism of animals and their vital processes, health and development $[27,28]$. The supplementation ration provided to the different batches made it possible to guarantee their health by making them resistant to mortality factors. These results confirm the work carried out by Bouatene et al [8]. These authors indicated that the incorporation of sogobalo in the feed of broilers helped to ensure the health of the animals during start-up. The mortalities noted only in the control batch (without sogobalo supplement) would be linked to the absence of sogobalo in this batch, which confirms the effectiveness of the sogobalo supplement in guaranteeing the health of the animals. The mortalities noted only in the control batch (without sogobalo supplement) would be linked to the absence of sogobalo in this batch, which confirms the effectiveness of the sogobalo supplement in guaranteeing the health of the animals. The use of coccidiosis would have avoided illnesses and deaths in the weeks preceding the week 3.

\section{Conclusion}

The use of sogobalo in different proportions (2.5 to 10\%) in the ration of broilers generated better performance (weight growth, weight gain, CI and mortality) than the control batch ( $0 \%$ sogobalo). This study has shown that sogobalo is an excellent supplement for broilers in the growth phase. It optimizes growth performance. The chickens fed a ration with $10 \%$ of sogobalo, had the best performance. These chickens have obtained the best average weights, the best weight gains and the best feed conversion. With its chemical pofile the sogobalo has improved the health of chickens. Thus, no mortality was recorded in batches of chickens fed with sogobalo.

\section{Compliance with ethical standards}

\section{Acknowledgments}

We would like to thank the company Labograin Africa for facilitating the incubation of the eggs of the flies. We also thank University of Nangui Abrogoua for the chemical analysis.

\section{Disclosure of conflict of interest}

All authors have read, understand and agreed to the submission guidelines, policies and submission declaration of the journal. All authors have approved the manuscript as submitted.

\section{References}

[1] Bebay CE. First assessment of the structure and importance of the commercial and family poultry sector in West Africa. Synthesis of national reports (Benin, Cameroon, Mali, Niger, Senegal, Togo), ECTAD / AGAPFA0. 2006 ; 47.

[2] Kouadio KE, Kreman K, Bamba KL, Kouadja GS. Effect of cassava peel flour on the zootechnical and economic performance of broiler chickens at start-up in Côte d'Ivoire. Journal of Animal and Plant Sciences. 2019; 42(2): 7237-7244.

[3] ITAVI. Community organic poultry farming in the face of European regulations for organic animal production: competitiveness and development prospects. 2002; 65. 
[4] Tougiani A, Idi M, Wowo H, Diawadou D. Effect of supplementation of flour from Moringa oleifera (Lam.) Leaves in broiler chicken production in Niger. International Journal of Biology and Chemical Science. 2017; 11(2): 722729.

[5] Lota D, Tamini M, Lamine F, Zacharia S. Small ruminant value chain in Burkina Faso: Situation analysis. Orstom, Nairobi. 2015; 156.

[6] Sana Y, Sangare M, Tingueri BL, Sanou J, Sawadogo L, Kabore-Zoungrana CY. Effect of the use of four rations based on Panicum maximum C1 on the zootechnical performance of Djallonké sheep, at Western Burkina Faso. Science of Life, Soil and Agronomy. 2020; 8(2): 2424-7235.

[7] Rivière. Feeding manual for domestic ruminants in the tropics. Collection Manuals and Precise Breeding. Institute of Breeding and Veterinary Medicine of Tropical Countries \& Ministry of Cooperation and Development. French documentation, 2nd edition. 1975; 525.

[8] Bouatene D, Koffi KM, Coulibaly A, Bohoua LG. Combined effect of feed presentation and Sogobalo supplementation on the Zootechnical performance of broilers in the start-up phase. International Journal of Advanced Research in Biological Sciences. 2020; 7(12): 134-143.

[9] Alla EY. Contribution to the optimization of the zootechnical results of a sheep farm: case of the Toumodi station. Master's internship report, Nangui Abrogoua University, Abidjan. 2011; 43.

[10] Cobb. Cobb broiler breeding guide, 2nd edition. Rennes. 2008; 65.

[11] Bouatene D, Bohoua LG, Dabonne S. Effet of moringa oleifera growth performance and healyh status of young post-weaning rabbits. Research Journal of poultry Sciences. 2011; 4(1): 7-13.

[12] Mingoas KJP, Awah-Ndukum J, Mampom BJ, Mfopit MY, Zoli PA. Effects of the farming system on zootechnical performance and blood and biochemical parameters in broilers in the peri-urban area of Ngaoundére, Cameroon. Journal of Animal and Plant Sciences. 2017; 32(1): 5079-5094.

[13] AOAC. Official method of analysis. 15th Edition Washington DC. 2005.

[14] AFNOR. French Association for Standardization. Collection of French standards for cereals and cereal products. 3rd Edition, France. 1991; 422.

[15] Alkoiret TI, Soulemanne AA, Gbangboche AB, Attakpa EY. Fattening performances of Djallonké sheep supplemented with cotton seed hulls in Benin. Livestock Research for Rural Development. 2007; $19(10): 141$.

[16] Ugwu CU, Aoyagi H, Uchiyama H. Photo bioreactors for mass cultivation of algae. Bioresource Technology. 2008; 99(10): 4021-4028.

[17] Kilemba MB, Kabemba TJ, Tshibangu MI. Trial of substitution of soybean meal by palm kernel meal in the ration of broilers in Lubumbashi: Effects on growth performance and economic parameters. International Journal of Innovation and Applied Studies. 2018; 1(25): 93-101.

[18] Abdou A. Effect of the substitution of maize by Faidherbia albida pods on the growth performance of broilers. Master's Degree Thesis. Animal Production Engineering. Cheikh Anta Diop University of Dakar, Senegal. 2012; 43.

[19] André BA, Serge EPM, Théodora GSA, Guy AM. Weight performance and characteristics of carcasses of broilers fed with feed rations based on Mucuna pruriens seeds. International Journal of Biology and Chemical Sciences. 2011; 5(6): 2306-2316.

[20] Mafouo NH, Teguia A, Kana JR, Mube HK., Diarra M. Effect of the level of incorporation of cassava flour in the ration on the growth performance of broilers. Livestock Research for Rural Development. 2011; $23: 76$.

[21] Hornick J, Akoutey A, Istasse L. Tropical animal nutrition and bromatology. The American Journal of Surgical Pathology. 2003; 27(9): 1183-1196.

[22] Washburn KW, Eberhart D. The effect of environmental temperature on fatness and efficiency of feed utilization (1166-1167). In: 18th World’s Poult. Cong., Nagoya, Japan, Jap. Poult. Sci. Ass. 04-09/9/1988,

[23] Tossou ML, Houndonougbo MF, Abiola FA, Chrysostomec AAM. Comparison of the production performance and organoleptic quality of the meat of three strains of broilers (Hubbard, Cobb and Ross) reared in Benin. Cams Review. 2014; 2(1): 30-35. 
[24] Tendonkeng F, Boukila B, Beguidé A, Pamo Tedonkeng E. Trial of substitution of soybean meal by flour from Moringa oleifera leaves in the finishing ration of broilers. International Conference on Strengthening Competitiveness in Semi-Industrial Poultry Farming in Africa (CIASA). INRAN. Dakar-Senegal. 2008; 16.

[25] Bello H. Trial of Incorporation of Moringa oleifera Leaf Flour into Feed in Senegalese Native Chickens: Effects on Growth Performance, Carcass Characteristics and Economic Outcome. Veterinary Doctor Diploma Thesis. Cheikh Anta Diop University of Dakar. 2010; 119.

[26] Laurel C. Evaluation of zootechnical and economic performance in the post reform period of broiler breeding (Cobb 500 and Jupiter strains) in the Dakar region. Doctoral thesis in veterinary medicine (State diploma). CHEIKH Anta Diop University of Dakar. Inter-State School of Veterinary Sciences and Medicine (E.I.S.M.V.). 2006; 115.

[27] Kühnemann H. The quadrupeds. In: Basic yard animals: sheep, bees. Edition Eugen Ulmer Bruxelles. 1992; 122127.

[28] Dayon JF, Arbelot B. Guide to poultry farming in Senegal. Memento of the agronomist. Edition CIRAD-ERNVT / DIREL. Montpellier. 2001; 113. 